\title{
Comparative evaluation of colposcopy, cytology and histopathology for diagnosis of cervical lesions
}

\author{
Rashmi Saxena*, Alpana Agrawal, Neelima Agarwal, Manisha Gupta, Divya Shubham, \\ Priyanka Rathore
}

Department of Obstetrics and Gynecology, Santosh Medical College and Hospital, Ghaziabad, Uttar Pradesh, India

Received: 29 May 2019

Revised: 16 July 2019

Accepted: 14 August 2019

*Correspondence:

Dr. Rashmi Saxena,

E-mail: rashmisaxena206@gmail.com

Copyright: $\odot$ the author(s), publisher and licensee Medip Academy. This is an open-access article distributed under the terms of the Creative Commons Attribution Non-Commercial License, which permits unrestricted non-commercial use, distribution, and reproduction in any medium, provided the original work is properly cited.

\begin{abstract}
Background: Cervical cancer is the fourth most frequent cancer globally in women with an estimated 570,000 new cases and 311,000 deaths in 2018 representing 6.6\% of all female cancers. To correlate the cytology, colposcopy and histopathology of cervical lesions in patients attending gynaecology OPD in a tertiary care centre, Ghaziabad.

Methods: 208 women were enrolled from Gynaecology OPD of Santosh Medical College and Hospital, Ghaziabad, irrespective of their chief complaints. Women aged 19-80 years were included in the study group. Those with pregnancy and already diagnosed or treated with CIN, Cervical cancer or Cervical HPV infection were excluded from the study. PAP-smear was taken for all the patients followed by colposcopy without waiting for PAP-smear report. Cervical biopsy was taken from patients with abnormal colposcopic findings ( 90 patients).

Results: Majority of women were in age group 30-39 years. 37.5\% had unhealthy, $21.6 \%$ had hypertrophied cervix and only $9.1 \%$ had normal cervix. It was found that PAP -smear has a sensitivity of $33.33 \%$, specificity of $92.59 \%$, accuracy of $68.89 \%$, positive predictive value of $75 \%$ and negative predictive value of $67.57 \%$. Test parameters calculated for colposcopy revealed that it has sensitivity of $73.33 \%$, specificity of $92 \%$, PPV of $64.7 \%$, NPV of $94.52 \%$ and accuracy of $88.89 \%$.

Conclusions: The results from the current study conclude that it is better to use cytology and colposcopy together as part of routine screening for cervical cancer rather than pap smear alone in order to detect maximum number of lesions.
\end{abstract}

Keywords: Cervical biopsy, Cervical cancer, Colposcopy, Cytology, Pap smear

\section{INTRODUCTION}

Cervical cancer is the fourth most frequent cancer globally in women with an estimated 570,000 new cases and 311,000 deaths in 2018 representing $6.6 \%$ of all female cancers. ${ }^{1}$ The vast majority, around $85 \%$ of cervical cancer cases and $87 \%$ of cervical cancer deaths occur in the less developed regions because of poor access to screening and treatment services. ${ }^{2}$ India alone accounts for one-quarter of the worldwide burden of cervical cancer. ${ }^{3}$ In India, 122,844 women are diagnosed with cervical cancer and 67,477 die from the disease every year. ${ }^{4}$ There were estimated 132,314 new cases and 73,337 deaths in the year $2015 .^{5}$ It is estimated that cervical cancer occur in approximately 1 in 53 Indian women as compared with 1 in 100 women in more developed regions of the world.

World Health organization considers cervical cancer as a preventable disease. This is because it can be diagnosed 
in its long precancerous phase. As it is a preventable condition and almost curable when diagnosed early, considerable efforts have been given to detect and treat it in its pre-invasive stage all over the world. ${ }^{6}$ With papsmear usage clinically, deaths caused by cervical cancer have decreased dramatically (70\% per year). Although Pap-smear test has 6\%-50\% false negative rates, this is still the most effective method for screening of precancerous lesions. Colposcopic examination is used for clarifying cytological diagnosis, to determine the lesion's place and size and biopsy of suspicious lesion to confirm the diagnosis. Unhealthy cervix is a group of cervical lesions, which include chronic cervicitis, cervical erosions, lacerations, polyps and leukoplakia. These lesions can harbour premalignant lesions even when Pap smear is negative. Under cervical screening programme, women with moderate or severe dyskaryosis or with persistent mild dyskaryosis of borderline change are referred for colposcopic examination of the cervix. Hence colposcopy might be of more use in detecting the premalignant lesions in these cases, than Pap smear alone. Our aim is to correlate cytology, colposcopy and histopathology for diagnosis of cervical lesions.

\section{METHODS}

From June 2018 to April 2019, study population comprised of 208 women, enrolled from Gynaecology OPD in Santosh Medical College irrespective of their chief complaints.

\section{Inclusion criteria}

- The women between 19 years to 80 years were included, who presented to Gynaecology OPD

- Irrespective of their chief complaint.

\section{Exclusion criteria}

- Women with pregnancy

- Those who were already diagnosed or treated with CIN

- Cervical cancer or cervical HPV infection were excluded from the study.

The detailed history was elicited from each case with respect to high risk factors for cervical cancer. This was followed by meticulous general and systematic examination including gynaecological examination. Care was taken to perform per speculum examination and take PAP-Test before bi-manual examination. It was ensured that the PAP-test was not performed if patient gave history of taking vaginal medication within seven days .PAP smear was taken for all the patients with unhealthy cervices using Ayres spatula after exposing cervix with Cusco's speculum. Samples smeared on two glass slides were sent in Coplin's jar containing fixative (95\% ethyl alcohol or equal parts of $95 \%$ ethyl alcohol and ether) to pathology department. The cytological interpretation of the smears was made according to the Bethesda system.
All these patients were a subjected to colposcopy without waiting for PAPS report. Digital colposcope model COLpro222DX was used for colposcopy. The colposcopic findings were classified as per International fedration of cervical pathology and colposcopy (IFCPC). All abnormal colposcopic lesions were biopsied using Tischler's punch biopsy forceps. Biopsy was sent to histopathology department in $10 \%$ formalin solution. Histopathological diagnosis was considered as "gold standard" for the final evaluation of PAP-Smear and colposcopic findings.

\section{Statistical analysis}

Statistical evaluation was done performed using chisquare test and Mcnemar's paired proportion test.

\section{RESULTS}

Out of 208 non pregnant women selected randomly from Gynaecology OPD in a tertiary centre irrespective of their chief complaint, Pap smear and colposcopy was done for all. 90 women with abnormal colposcopic findings were subjected to biopsy. Histopathological findings are shown in Table 1. Out of 90 cases, 54 (60\%) were inflammatory, 21 showed koilocytosis suggestive of HPV, 3 cases each of CIN1 and CIN3, 1 case of CIN2 and 8 cases were diagnosed to have CA. All patients with inflammation were grouped as negative lesions while patient with koilocytosis, CIN 1, CIN 2, CIN 3 and CA were grouped as positive lesions for statistical evaluation.

Table 1: Histopathological diagnosis in study group.

\begin{tabular}{|lll|}
\hline Histopathology & $\mathbf{N}=90$ & $\%$ \\
\hline Inflammation & 54 & 60 \\
\hline Koilocytosis (HPV) & 21 & 23.33 \\
\hline CIN 1 & 3 & 3.33 \\
\hline CIN 2 & 1 & 1.11 \\
\hline CIN 3 & 3 & 3.33 \\
\hline Carcinoma & 8 & 8.90 \\
\hline
\end{tabular}

Table 2 shows a correlation of age with histopathology of biopsies taken. Majority of women in study group were between 30-39 years (42.8\%) followed by 40-49 years (24\%) and 20-29 years (16.8\%). From Table 2, it is evident that cervicitis was the most common lesion amongst the patients of age group 30-39 years (40.7\%). HPV infection was more prevalent in age group 40-49 years. CIN was more commonly present in age group 3039 years. CA was present more in age group 50-59 years and above 60 years.

As shown in Table 3, only $9.1 \%$ had normal looking cervix, $37.5 \%$ had an unhealthy cervix suspicious of malignancy and rest $53.4 \%$ had a hypertrophied cervix, cervical erosion or cervicitis. The association of positive group of lesion (HPV, CIN 1, CIN 2, CIN 3, CA) with 
unhealthy cervix was found to be significant (z-statistics $=33.29, \mathrm{p}<0.0001$ ).

Table 4 shows the results of PAP-smear in all 208 women. Out of 208 PAP Smears $12(5.8 \%)$ were inadequate for opinion and was included in negative group for evaluation. Majority were inflammation
(NILM) comprising of $173(83.2 \%)$ of cases. ASCUS was found in 9 out of $208(4.3 \%)$ of women. Only 5 cases of LSIL (2.4\%), 3 cases of HSIL (1.4\%) and 6 cases of CA $(2.9 \%)$ were diagnosed on cytology.

Table 2: Correlation of age distribution with histopathological lesions.

\begin{tabular}{|c|c|c|c|c|c|c|c|c|}
\hline \multirow{3}{*}{$\begin{array}{l}\text { Age } \\
\text { group } \\
\text { (years) }\end{array}$} & \multicolumn{8}{|c|}{ Histopathology } \\
\hline & \multirow{2}{*}{$\begin{array}{l}\text { Total }(\%) \\
\mathbf{N}=208\end{array}$} & \multirow{2}{*}{$\begin{array}{l}\text { Biopsied } \\
\mathrm{N}=90\end{array}$} & \multirow{2}{*}{$\begin{array}{l}\text { Negative group } \\
\text { Inflammation } \\
\mathrm{N}=54\end{array}$} & \multicolumn{5}{|c|}{ Positive group } \\
\hline & & & & $\begin{array}{l}\text { HPV } \\
\mathrm{N}=21\end{array}$ & $\begin{array}{l}\text { CIN } 1 \\
\mathbf{N}=3\end{array}$ & $\begin{array}{l}\text { CIN } 2 \\
\mathbf{N}=1\end{array}$ & $\begin{array}{l}\text { CIN } 3 \\
\mathbf{N}=3\end{array}$ & $\begin{array}{l}\text { Cancer } \\
\mathrm{N}=8\end{array}$ \\
\hline$<20$ & $1(0.48 \%)$ & - & - & - & - & - & -- & - \\
\hline $20-29$ & $35(16.8 \%)$ & $16(17.8 \%)$ & 11 & 4 & 1 & - & - & - \\
\hline $30-39$ & $89(42.8 \%)$ & $36(40 \%)$ & 22 & 6 & 1 & 1 & 3 & 3 \\
\hline $40-49$ & $50(24 \%)$ & $19(21.1 \%)$ & 10 & 9 & - & - & - & - \\
\hline $50-59$ & $22(10.6 \%)$ & $12(13.3 \%)$ & 7 & 2 & 1 & - & - & 2 \\
\hline$>60$ & $11(5.2 \%)$ & $7(7.8 \%)$ & 4 & - & - & - & - & 3 \\
\hline
\end{tabular}

Table 3: Correlation of gross appearance of cervix with histopathology.

\begin{tabular}{|c|c|c|c|c|c|c|c|c|}
\hline \multirow{3}{*}{$\begin{array}{l}\text { Gross appearance } \\
\text { of cervix }\end{array}$} & \multirow{3}{*}{$\begin{array}{l}\text { Total cases } \\
\mathrm{N}=208\end{array}$} & \multirow{3}{*}{$\begin{array}{l}\text { Total Biopsied } \\
\mathbf{N}=90(\%)\end{array}$} & \multicolumn{6}{|l|}{ Histopathology } \\
\hline & & & \multirow{2}{*}{$\begin{array}{l}\text { Negative group } \\
\text { INFL } \\
\mathrm{N}=\mathbf{5 4}\end{array}$} & \multicolumn{5}{|c|}{ Positive group } \\
\hline & & & & $\begin{array}{l}\text { HPV } \\
N=21\end{array}$ & $\begin{array}{l}\text { CIN 1 } \\
\mathrm{N}=3\end{array}$ & $\begin{array}{l}\text { CIN2 } \\
N=1\end{array}$ & $\begin{array}{l}\text { CIN3 } \\
\mathbf{N}=3\end{array}$ & $\begin{array}{l}\mathrm{CA} \\
\mathrm{N}=8\end{array}$ \\
\hline Normal & $19(9.1 \%)$ & $3(3.3 \%)$ & 2 & 1 & - & - & - & - \\
\hline Cervicitis & $35(16.8 \%)$ & $7(7.8 \%)$ & 3 & 3 & 1 & - & - & - \\
\hline Erosion & $31(14.9 \%)$ & $12(13.3 \%)$ & 9 & 3 & - & - & - & - \\
\hline Hypertrophied & $45(21.6 \%)$ & $21(23.3 \%)$ & 14 & 6 & 1 & - & - & - \\
\hline Unhealthy & $78(37.5 \%)$ & $47(52.2 \%)$ & 26 & 8 & 1 & 1 & 3 & 8 \\
\hline
\end{tabular}

Table 4: Pap smear results.

\begin{tabular}{|ll|l|}
\hline PAP smear findings & No. $(\mathrm{N}=208)$ & $\%$ \\
\hline Unsatisfactory & 12 & 5.8 \\
\hline NILM & 173 & 83.2 \\
\hline ASCUS & 9 & 4.3 \\
\hline LSIL & 5 & 2.4 \\
\hline HSIL & 3 & 1.4 \\
\hline CA & 6 & 2.9 \\
\hline
\end{tabular}

Inflammation NILM), unsatisfactory lesions and ASCUS were considered as negative group, while LSIL, HSIL and CA were considered as positive group of lesions for statistical evaluation.

Table 5 describes the correlation of cytology with histopathology Out of 173 inflammatory smears on cytology, only 65 were biopsied. Out of these 47 (72\%) smears were confirmed to be inflammatory, 15 (23\%) showed HPV infection; only $2(3 \%)$ cases were diagnosed as CIN 1 and 1 (2\%) case was found to be CA on histopathology which was missed on cytology.
The test parameters as calculated on total biopsied cases revealed that PAP smear has a sensitivity of $33.33 \%$, specificity of $92.59 \%$, accuracy of $68.89 \%$, positive predictive value of $75 \%$ and negative predictive value of $67.57 \%$

Table 6 shows correlation of colposcopic impression with histopathology. It is evident from Table 6 that out of 208 cases who were subjected for colposcopy without waiting for PAP-Smear report, 25 (12\%) cases were reported to have normal colposcopic appearance, out of which only three were biopsied which were found to be inflammatory. $137 \quad(65.9 \%)$ cases diagnosed as Inflammation on colposcopy. Out of these 137 cases only 60 cases were biopsied which confirmed 40 cases as inflammation, 17 as HPV and 3 cases as CIN1.

Out of $28(13.5 \%)$ cases diagnosed as Ectropion on colposcopy, 10 cases were biopsied which showed 8 cases of inflammation, 1 case of HPV and 1 case of CIN3. Out of 3 cases diagnosed as CIN1 on colposcopy, 2 were biopsied which confirmed one case to be CIN1, 
but other case was found to be inflammation. Out of 3 cases diagnosed asCIN2, all were biopsied; 2 were found to have CIN3, while other was confirmed to be HPV. Out of 4 cases of CIN 3 on colposcopy 2 were confimed as
CA, 1 case as CIN2 and 1 case was found to be inflammatory. 8 cases diagnosed as CA on colposcopy, 6 cases were confirmed as CA, 1 case as CIN2 and 1 case was found to have inflammation only.

Table 5: Correlaton of cytology with histopathology.

\begin{tabular}{|c|c|c|c|c|c|c|c|}
\hline \multirow{3}{*}{ PAP findings } & \multirow{3}{*}{$\begin{array}{l}\text { Total biopsied } \\
\mathrm{N}=90(\%)\end{array}$} & \multicolumn{6}{|l|}{ Histopathology } \\
\hline & & \multirow{2}{*}{$\begin{array}{l}\text { Negative group } \\
\text { INFL } \\
\mathrm{N}=54\end{array}$} & \multicolumn{5}{|c|}{ Positive group } \\
\hline & & & $\begin{array}{l}\text { HPV } \\
\mathrm{N}=21\end{array}$ & $\begin{array}{l}\text { CIN 1 } \\
\mathbf{N}=3\end{array}$ & $\begin{array}{l}\text { CIN } 2 \\
N=1\end{array}$ & $\begin{array}{l}\text { CIN3 } \\
\mathbf{N}=3\end{array}$ & $\begin{array}{l}\mathrm{CA} \\
\mathrm{N}=8\end{array}$ \\
\hline Unsatisfactory & $7(7.8)$ & 3 & 2 & - & - & - & 2 \\
\hline NILM & $65(72.2)$ & 47 & 15 & 2 & - & - & 1 \\
\hline ASCUS & $2(2.2)$ & - & 2 & - & - & - & \\
\hline LSIL & $4(4.4)$ & 1 & 2 & - & - & 1 & - \\
\hline HSIL & $6(3.3)$ & 2 & - & 1 & - & 2 & - \\
\hline $\mathrm{CA}$ & $6(6.7)$ & 1 & - & - & 1 & - & 5 \\
\hline
\end{tabular}

Table 6: Correlation of colposcopic findings with histopathology.

\begin{tabular}{|c|c|c|c|c|c|c|c|c|}
\hline \multirow{3}{*}{$\begin{array}{l}\text { Colposcopic } \\
\text { impression }\end{array}$} & \multirow{3}{*}{$\begin{array}{l}\text { Total cases } \\
\mathrm{N}=208(\%)\end{array}$} & \multirow{3}{*}{$\begin{array}{l}\text { Total cases } \\
\text { biopsied } \\
\mathrm{N}=90(\%)\end{array}$} & \multicolumn{6}{|l|}{ Histopathology } \\
\hline & & & \multirow{2}{*}{$\begin{array}{l}\text { Negative group } \\
\text { INFL } \\
\mathrm{N}=54\end{array}$} & \multicolumn{5}{|c|}{ Positive group } \\
\hline & & & & $\begin{array}{l}\text { HPV } \\
\mathrm{N}=21\end{array}$ & $\begin{array}{l}\text { CIN } 1 \\
\mathbf{N}=3\end{array}$ & $\begin{array}{l}\text { CIN } 2 \\
N=1\end{array}$ & $\begin{array}{l}\text { CIN } 3 \\
\mathbf{N}=3\end{array}$ & $\begin{array}{l}\mathrm{CA} \\
\mathrm{N}=8\end{array}$ \\
\hline Normal & $25(12)$ & $3(3.3)$ & 3 & - & - & - & - & - \\
\hline INFL & $137(65.9)$ & $60(66.7)$ & 40 & 17 & 3 & - & - & - \\
\hline Ectropion & $28(13.5)$ & $10(11.1)$ & 8 & 1 & - & - & 1 & - \\
\hline CIN1 & $3(1.4)$ & $2(2.2)$ & 1 & 1 & - & - & - & - \\
\hline CIN2 & $3(1.4)$ & $3(3.3)$ & - & 1 & - & - & 2 & - \\
\hline CIN3 & $4(1.9)$ & $4(4.4)$ & 1 & - & - & 1 & - & 2 \\
\hline $\mathrm{CA}$ & $8(3.9)$ & $8(8.9)$ & 1 & 1 & - & - & - & 6 \\
\hline
\end{tabular}

Test parameters calculated on total biopsied cases revealed that colposcopy has sensitivity of $73.33 \%$, specificity of $92 \%$, PPV of $64.7 \%$, NPV of $94.52 \%$ and accuracy of $88.89 \%$.

\section{DISCUSSION}

Since 1943, Pap smear cytology has been used for the screening of cervical cancer. ${ }^{7}$ However, the best method for cervical cancer screening still remains unclear. Literature recommends different methods ranging from simple cytology, colposcopy, and human papilloma virus deoxyribonucleic acid (HPV DNA) testing or even repeat cytology cytological screening is not specificity sufficient to successfully identify the women with due to various well recognised inherent limitations of cervical cytology, a percentage of high-grade lesions are missed on Pap smear. ${ }^{7-11}$ Studies suggest a wide variation of sensitivity of Pap smear ranging from as low as $30 \%$ to $70 \% .^{12} \mathrm{~A}$ prospective analytical study conducted in India in 2008 also showed lack of agreement of cytology with histopathology and the study concluded that even the patients with persistent inflammatory Pap smear can harbour a high proportion of CIN. ${ }^{13}$ In our study Papsmear has sensitivity of $33.33 \%$, specificity of $92.59 \%$, positive predictive value of $75 \%$ and negative predictive value of $67.57 \%$. Out of 65 non inflammatory smears, one case of CA and 2 cases of CIN were missed on PAPSmear. 15 cases of NILM on PAP-Smear were found to have koilocytic changes (HPV) on histopathology. The accuracy of PAP Smear in our study was $68.89 \%$ which is comparable to the findings in various studies, $76 \%$ by Chaudhary et al, $73.2 \%$ by Jain et al, $74.5 \%$ by Naik et al. ${ }^{14-16}$ However, Mallur et al and Ashmita et al concluded the accuracy of PAP smear to be $40 \%$ and $33.96 \% .^{17,18}$

Colposcopy is more than a simple intermediate link between cytologic screening and histologic diagnosis. In the presence of an abnormal cytological smear, a tissue diagnosis is essential before proceeding with definitive treatment. The most common indication for colposcopic investigation of cervix is abnormal cytological smears followed by clinical suspected cervical lesions. In our study colposcopy has sensitivity of $73.33 \%$ which is much higher than the sensitivity of Pap smear i.e. $33.33 \%$. Specificity of colposcopy was $92 \%$ which was 
comparable to that of Pap smear. Colposcopy has PPV of $64.7 \%$ and NPV of $94.52 \%$ for the diagnosis of cervical lesions. Accuracy of colposcopy was found to be $88.89 \%$ which corresponds to the findings of other studies, $86.54 \%$ by Ashmita et al, $80 \%$ by Mallur et al, $80.50 \%$ by Chaudhary et al and $98.3 \%$ by Boicea et al. ${ }^{14,17-19}$ Expertise and experience is necessary for proper interpretation of colposcopy. Histopathology is considered as gold standard in our study. Sensitivity and specificity of Pap smear and colposcopy is compared to the colposcopic directed biopsy positive cases. It is evident that colposcopy had higher sensitivity and specificity as compared to cytology. Also positive predictive value is high for colposcopy as compared to cytology. Hence colposcopy is more useful in detecting premalignant and malignant lesions of the cervix. Colposcopy and cytology used together in patients of cervical lesions have a relatively higher chance of detecting squamous intraepithelial lesions/malignancy as compared to either procedure when performed alone. ${ }^{20}$ Also colposcopic directed biopsy is much more reliable in picking up true positive cases as compared to biopsy through visual inspection procedures.

\section{CONCLUSION}

In our study, colposcopy produced higher levels of accuracy, sensitivity and negative predictive value than Pap smear in diagnosing cervical lesions. Since cervical cancer is the most common gynaecological cancer in developing countries like India and the accuracy of the Pap smear is low, hence it may be better to utilise both tests as they complement each other in screening of premalignant lesions of cervix. The results from the current study conclude that it is better to perform combination screening tests as part of routine screening for cervical cancer rather than PAP-smear alone in order to detect maximum number of lesions.

Funding: No funding sources

Conflict of interest: None declared

Ethical approval: The study was approved by the Institutional Ethics Committee

\section{REFERENCES}

1. Bray F, Ferlay J, Soerjomataram I, Siegel RL, Torre LA, Jemal A. Global cancer statistics 2018: GLOBOCAN estimates of incidence and mortality worldwide for 36 cancers in 185 countries. CA Cancer J Clin. 2018;68(6):394-424.

2. Suraiya UB, Ratnam SS, Rao KB, Arulkumar S. Cancer screening in gynecology. Obstetrics and gynecology. New Delhi: Orient Longman; 1994:454464.

3. Bobdey S, Sathwara J, Jain A, Balasubramaniam G. Burden of cervical cancer and role of screening in India. Indian J Med Paediatr Oncol. 2016;37(40);278-85.
4. ICO Information Centre on HPV and cancer (Summary Report 2014-08-22). Human Papilloma virus and Related Diseases in India; 2014.

5. Ferlay J, Soerjomataram I, Ervik M, Dikshit R, Eser S, Mathers C, et al. GLOBOCAN 2012 v1.0. Cancer Incidence and Mortality Worldwide: sources, methods and major patterns in GLOBACON2012. Int J Cancer. 2015;136(5)E359-86.

6. Sivanessartnam V. Pathology and management of CIN lesion of the cervix. In: Ratnam SS, Rao KB, Arulkumaran S. eds. Obstetrics and gynecology for post graduate. $2^{\text {nd }}$ ed. New Delhi: Orient Longman; 1999:364-379.

7. Anttila A, Ronco G, Clifford G, Bray F, Hakama M, Arbyn M. Cervical cancer screening programmes and policies in 18 European countries. $\mathrm{Br} \mathrm{J}$ Cancer. 2004;91:935-41.

8. Smith RA, Cokkinides V, Eyre HJ. American cancer society. American Cancer Society guidelines for the early detection of cancer, 2004. CA Cancer J Clin. 2004;54:41-52.

9. Cervical cancer screening and prevention. Practice Bulletin NO 168. American College of Obstreticians and Gynaecologists. Obstet Gynecol. 2016;128:e11130.

10. Massad LS, Jeromino J, Hormuzd A, Katki, Schiffman M. The accuracy of colposcopic grading for detection of high grade cervical intraepithelial neoplasia, J Low Genital Tract Dis. 2009;13:137-44.

11. Chacho MS, Mattie ME, Schwartz PE. Cytohistologic correlation rates between conventional Papanicolaou smears and Thin Prep cervical cytology: a comparison. Cancer. 2003;99:35-40.

12. Nanda K, McCrory DC, Myers ER, Bastian LA, Hasselblad V, Hickey JD, et al. Accuracy of the Papanicolaou test in screening for and follow-up of cervical cytologic abnormalities: a systematic review. Ann Intern Med. 2000;132:810-9.

13. Dasari P, Rajathi S, Kumar SV. Colposcopic evaluation of cervix with persistent inflammatory Pap smear: a prospective analytical study. Cytojournal. 2010;7:16.

14. Chaudhary RD, Inamdar SA, Hariharan C. Correlation of diagnostic efficacy of unhealthy cervix by cytology, colposcopy and histopathology in women of rural areas. Int $\mathbf{J}$ Reprod Contracept Obstet Gynecol. 2014;3(1):213-8.

15. Jain V, Vyas AS. Cervical Neoplasia-cytohistological correlation (Bethesda System) a study of 276 cases. J Cytol Histol. 2010;1:106.

16. Naik R, Minj MM, Panda R, Satpathi S, Behera PK, Panda KM. Cytohistological correlation and accuracy of the pap smear test in diagnosis of cervical lesions: a hospital based cross-sectional study from Odisha, India. Medical Sci. 2015;3:242-9.

17. Mallur PR, Desai BR, Anita D, Geeta D, Bhavana S, Pallav G. Sequential screening with cytology and colposcopy in detection of cervical Neoplasia. J South Asian Feder Obst Gynae. 2009;1(3):45-8. 
18. Ashmita D, Shakuntala PN, Rao S, Sharma SK, Geethanjali S. Comparison and correlation of PAP smear, colposcopy and histopathology in symptomatic women and suspicious looking cervix in a tertiary hospital care centre. Int J Health Sci Res. 2013;50(5):1-5.

19. Boicea A, Patrascu A, Surlin V, Iliescu D, Schenker M, Chiutu L. Correlations between colposcopy and histologic results from colposcopically directed biopsy in cervical precancerous lesions. Rom J Morphol Embryol. 2012;53(3 Suppl):735-41.

20. Chaudhary RD, Inamdar SA, Hariharan C. Correlation of diagnostic efficacy of unhealthy cervix by cytology, colposcopy and histopathology in women of rural areas. Int J Reprod Contracept Obstet Gynecol. 2014;3(1):213-8.

Cite this article as: Saxena R, Agrawal A, Agarwal N, Gupta M, Shubham D, Rathore P. Comparative evaluation of colposcopy, cytology and histopathology for diagnosis of cervical lesions. Int J Reprod Contracept Obstet Gynecol 2019;8:3584-9. 